\title{
Effect of Gasoline Exposure on Hematological Parameters of Gas Station Workers in Mekelle City, Tigray Region, Northern Ethiopia
}

\author{
Gebre Teklu' \\ Mikias Negash ${ }^{2}$ \\ Tsegay Asefaw' \\ Feven Tesfay (iD) \\ Gebreslassie Gebremariam (iD)' \\ Gebreyohannes Teklehaimanot (iD) \\ Mistire Wolde ${ }^{2}$ \\ Aster Tsegaye (iD) ${ }^{2}$ \\ 'Department of Medical Laboratory \\ Science, College of Health Sciences, \\ Mekelle University, Mekelle, Ethiopia; \\ ${ }^{2}$ Department of Medical Laboratory \\ Sciences, College of Health Sciences, \\ Addis Ababa University, Addis Ababa \\ Ethiopia
}

Background: The adverse health effects of chronic gasoline exposure may be related to impairment of the hematopoietic system with bone marrow suppression, an increased risk of blood cell morphology abnormality and developing cancer.

Objective: To assess the effect of gasoline exposure on hematological parameters among gas station workers in Mekelle City, Tigray Region, Northern Ethiopia.

Methods: This cross-sectional study was carried out on 43 subjects (exposed group) and 77 subjects (unexposed group) with matched age and sex. Socio-demographic characteristics and duration of exposure data were collected using a structured questionnaire and an observation checklist. Sysmex XP-300 was used for hematological analysis and stained peripheral blood smear was examined for any abnormality. Data were entered and analyzed using SPSS version 23.

Results: Of exposed individuals, 28/43 (65.1\%) and 49/77 (63.6\%) of controls were males. The average exposure time was $5.19 \pm 4.38$ years, with an average working hour of 11.74 \pm 1.89 hours/day. The mean RBC count $\left(10^{12} / \mathrm{L}\right)$, HCT $(\%)$, HGB (g/dl) and platelets count $\left(10^{9} / \mathrm{L}\right)$ of the exposed group were significantly lower $(4.88 \pm 0.573,43.29 \pm 3.71,15.04 \pm 1.33$ and $248.95 \pm 58.19)$ compared with controls $(5.35 \pm 0.533,44.95 \pm 3.10,15.59 \pm 1.26$ and 292.45 $\pm 62.17)$ at $\mathrm{p}<0.05$, respectively. The $\mathrm{MCH}$ (pg) $(30.48 \pm 2.06$ vs $29.52 \pm 1.66)$ and MCHC (g/ dl) (34.83 \pm 0.988 vs $34.32 \pm 0.927)$ were significantly higher in the exposed group compared with controls $(\mathrm{p}<0.05)$. HCT, RBC, HGB and platelet counts were significantly decreased with increased years of exposure $(\mathrm{p}<0.05)$. The peripheral blood film examination revealed basophilic stippling and macrocytosis in $9.3 \%$ of the exposed group.

Conclusion: Long-term exposure to gasoline at gas stations affected RBC parameters and platelet count. A significant negative correlation was noted between duration of exposure and HGB, HCT and platelet count, warranting implementation of protective measures at gas stations.

Keywords: gas station, gasoline, hematological parameters, petroleum

\section{Introduction}

Changes in blood parameters are probably the early detectable variations under stress conditions like gasoline exposure and used for assessing the health condition of exposed individuals. ${ }^{1,2}$

Exposure to several chemicals is implicated in the derangement of hematological profile with characteristic pancytopenia, mainly aplastic anemia and an increased risk of developing cancer (acute myeloblastic leukemia). Morphological effect on red blood cells (RBCs) like microcytosis and inclusion also occurs. ${ }^{3-5}$ Gas 
station workers are exposed to gasoline by inhalation during refilling or through contaminated food at service stations. ${ }^{6}$ Gasoline is a very volatile liquid, with several organic and inorganic constituents. ${ }^{6}$ Some of its constituents are known to be highly toxic or carcinogenic to humans. $^{7,8}$ Many of the toxicological effects associated with the exposure to gasoline can be attributed to specific components of gasoline, such as benzene, toluene, ethylene and xylene, which are also known as volatile organic compounds (VOCs). ${ }^{8}$

Effects of gasoline exposure are time dependent. If unprotected individuals are exposed for long periods, it may lead to permanent suppression of bone marrow functioning, accompanied by reduction in the formation of new blood cells causing aplastic anemia., ${ }^{1,9,10}$ Such disorders are believed to be caused by toxic Benzene metabolites. Benzene is metabolized in the liver to its primary metabolite phenol by cytochrome P4502E1 (CYP2E1) through the benzene oxide intermediate. It is subsequently metabolized by CYP2E1 to hydroquinone (HQ). ${ }^{11,12} \mathrm{HQ}$ is transported to the bone marrow and oxidized to benzoquinones, which eventually release reactive oxygen species (ROS) damaging hematopoietic cells. ${ }^{14,15}$ Therefore, chronic exposure to benzene is believed to be associated with many bone marrow failures and hematological malignancies like acute myeloid leukemia (AML), aplastic anemia myelodysplastic syndrome, acute lymphoblastic leukemia and chronic myeloid leukemia. ${ }^{13,16}$

Several authors have reported that toxicity of gasoline comes mainly from benzene metabolites. ${ }^{11-15}$ According to existing evidence, petroleum hydrocarbons have the potential to cause deoxyribo nucleic acid (DNA) damage in gasoline-exposed individuals and exposure to petrol vapor induces genotoxic effects, confirming that the gas station workers have a high risk of cancer due to their daily occupational exposure. ${ }^{17,20,21}$ Once gasoline is inhaled, benzene, as the main ingredient of gasoline, enters the lungs then is passed to the blood stream from which it goes to the liver, where three main phenolic metabolites of benzene are released, transient phenol and accumulated hydroquinone and catechol, in relatively high concentrations. $^{18,19}$ Benzene is a lipophilic agent, so its metabolites go directly to fatty tissues such as bone marrow where actual toxic species are generated. ${ }^{15,19,22}$

It has been shown that genetic polymorphisms of xenobiotic metabolizing enzymes may modulate the susceptibility of individuals to toxic compounds like the glutathione
S-transferase (GST) superfamily, which plays an important role in detoxification of various toxicants. ${ }^{23}$ It is reported that these enzymes are involved in detoxification of several toxins, including some of the compounds present in gasoline. ${ }^{24}$ Evidence is provided also for wide toxic effects of benzene metabolites with prolonged exposure including: pancytopenia and leucopenia ${ }^{24-26}$ and other blood disorders such as leukemia. ${ }^{26}$ The gasoline component has a known carcinogen primarily affecting the hematopoietic system. The effects of systemic gasoline exposure can cause acute and chronic clinical disorders of the cardiovascular, respiratory, neurological, gastrointestinal, liver, renal and dermatological local effects, and immunological, metabolic and allergic reactions. While several studies pointed to the risk of occupational exposure to gasoline on hematological profiles and other tests of the above disorders, there are no published studies in this regard in the country, so this study tries to address only the hematological profile of exposed attendants.

\section{Materials and Methods Study Design and Setting}

A comparative cross-sectional study was conducted upon gas station attendants at Mekelle City during the period from January to April 2018. Mekelle is capital city of Tigray Regional State and is located in the Northern part of Ethiopia, at $783 \mathrm{~km}$ from the capital city of Ethiopia, Addis Ababa, with an elevation of 2254 meters (7395 feet) above sea level.

\section{Study Population Study Groups}

There were 13 gas stations in Mekelle City and around the city. The study included 43 out of the total 49 gas station attendants, with a response rate of $87.8 \%$. Adult males and females aged 18-60 years, working for at least six months at those gas stations and who volunteered to participate in the study were recruited.

\section{Comparison Group}

Seventy-seven age and sex matched apparently healthy non-exposed control participants from Mekelle University, Ayder Comprehensive Specialized Hospital Department of Medical Laboratory staff and graduate students were recruited in this study by using a nonprobability convenient sampling method.

Participants with the following data were excluded from the study: history of any acute infection, chronic 
diseases, individuals on medication affecting blood cell count and individuals with a blood disorder already.

\section{Data Collection Process}

Data was collected over a three-month period by questionnaire interviews focusing on socio-demographic data, years of exposure, working time (hours/day), knowledge of gasoline exposure, utilization of protective methods, health status, smoking habits and medication history.

\section{Specimen Collection and Analysis}

About $5 \mathrm{~mL}$ of blood was collected in Ethylene a Diamine Tetraacetic Acid (EDTA) test tube from participants who completed the questionnaire and who agreed to give blood. Four workers did not volunteer to participate, and an additional two were excluded due to acute infection and pregnancy cases. Complete blood count (CBC) tests, including total $\mathrm{RBC}$ count, total $\mathrm{WBC}$ count, $\mathrm{Hb}$ and $\mathrm{Hct}$ levels, total platelet, $\mathrm{MCV}, \mathrm{MCH}, \mathrm{MCHC}$, mean platelet volume, and red blood cell distribution width (RDW), absolute and relative counts of lymphocyte and neutrophil, were analyzed using the 3-part hematological auto analyzer (Sysmex XP-300, Sysmex Corporation, Kobe, Japan) within 2 hours of blood collection. Sysmex XP-300 performs rapid and accurate analysis of a 17-parameter $\mathrm{CBC}$, including a 3-part WBC differential. ${ }^{36}$

\section{Data Quality Control}

The quality of the collected blood and the participant information were ensured by collecting and processing using a standard operating procedure to address preanalytical, analytical and post-analytical errors. Blood was collected using a standard operating procedure. The blood sample container was labeled with the participant's unique code to minimize errors. The quality of the collected samples was checked for hemolysis, clot, correct volume, etc. Site assessment and pre-test of data collection were done prior to data collection and the data was checked for completeness, quality and clarity of questionnaire and modified accordingly.

The reliability of the study findings, especially the analytical part, was guaranteed by implementing a quality control (QC) sample for the complete blood count and peripheral morphology through the whole process of laboratory works. The results of the complete blood count $(\mathrm{CBC})$ and peripheral morphology were registered with correct values and units. Data were entered using double-entry method to trace data entry errors.
Specimens were transported and analyzed within 2 hours of collection and, if delayed, refrigerated at $4-8{ }^{\circ} \mathrm{C}$.

\section{Data Analysis}

Data were entered and statistically analyzed using the Statistical Package for the Social Sciences (SPSS) version 23. The one-way ANOVA test was used for analysis of variance between quantitative dependent variables and qualitative variables, such as the relationship between hematological parameters by duration of work, age group, level of education and so on. The multiple comparisons were made using the post hoc test for the duration of exposure. The independent samples $t$-test procedure was used to compare means of quantitative variables between gas station workers' and controls' hematological parameters. Pearson correlation coefficient was used to assess measured parameters with years of exposure, working hours and age. P-values less than $5 \%(\mathrm{p}<0.05)$ at $95 \%$ confidence intervals was taken as statistically significant.

\section{Ethical Considerations}

The study was conducted after approval by the research and ethics committee of the Department of Medical Laboratory Sciences, College of Health Science of Addis Ababa University. The research committee is an authorized professional body for giving permission to researchers to conduct their studies with ethical concern in the area. An official letter of request was sent to Mekelle University, Ayder Comprehensive Specialized Hospital to obtain approval to carry out hematological analysis in the central laboratories. Written informed consent to voluntarily participate was obtained from all study participants after explaining the purpose of the study. The confidentiality of the data was also assured. After all, this study was conducted in accordance with the Declaration of Helsinki.

\section{Results}

\section{Socio-Demographic Characteristics of the Study Participants}

In this study, a total of 120 participants, 43 exposed and 77 controls, was enrolled. There was no statistically significant age and sex difference between the exposed and the control groups $(\mathrm{p}=0.444, \mathrm{p}=0.540)$, respectively (Table 1). 
Table I Socio-Demographic Profile of the Study Group Using $t$-Test and $\chi^{2}$ Tests at Mekelle City, Tigray Region, Northern Ethiopia, from January to March $2018(n=120)$

\begin{tabular}{|l|l|l|l|}
\hline Confounding Factors & Gas Station Attendant (n=43) & Control Group (n=77) & Test of Significance \\
\hline Gender & & $49(63.6 \%)$ & \\
Male $n(\%)$ & $28(65.1 \%)$ & $28(36.4 \%)$ & $\chi^{2}=0.008, \mathrm{p}=0.540$ \\
Female $\mathrm{n}(\%)$ & $15(34.9 \%)$ & & \\
\hline Age in years n (\%) & & $29(37.7 \%)$ & \\
I9-26 & $17(39.5 \%)$ & $37(48.1 \%)$ & \\
$27-34$ & $16(37.2 \%)$ & $2(11.7 \%)$ & \\
$35-44$ & $6(14 \%)$ & $29.06 \pm 6.07$ & $\mathrm{t}=0.768, \mathrm{p}=0.444$ \\
$>45$ & $4(9.3 \%)$ & & \\
Mean \pm SD & $30.09 \pm 8.49$ & & \\
\hline Marital status & & & \\
Single $\mathrm{n}(\%)$ & $22(51.2 \%)$ & $21(48.8 \%)$ & \\
Married $\mathrm{n}(\%)$ & & & \\
\hline
\end{tabular}

Abbreviation: SD, standard deviation.

\section{Years of Exposure, Working Hours and Awareness Related to Gasoline Exposure} The average exposure time was $5.19 \pm 4.38$ years (minimum 8 months and maximum 16 years), with an average daily exposure of $11.74 \pm 1.89$ hours. The working hour was more than 12 hours/day among $58.1 \%$ of the participants. The highest number of workers, 17 (39.5\%), had worked in the gas station for less than two years, whereas $12(27.9 \%)$ and $14(32.6 \%)$ of them worked $3-7$ and for more than 8 years, respectively. All the study population had no history and habit of smoking cigarettes.

\section{Hematological Profile of Gasoline} Exposed and Control Groups

The means and standard deviations of hematological indices of exposed and unexposed groups are presented in Table 2. These results show that the hematological markers in both study groups were within the normal

Table 2 Complete Blood Count Picture of the Study Group Using Independent Samples t-Test at Mekelle City, Tigray Region, Northern Ethiopia, from January to March $2018(n=120)$

\begin{tabular}{|c|c|c|c|c|c|}
\hline \multirow[t]{2}{*}{ Parameters } & \multirow[t]{2}{*}{ Exposed Group $(n=43)($ mean $\pm S D)$} & \multirow[t]{2}{*}{ Control Group $(n=77)($ mean $\pm S D)$} & \multicolumn{3}{|c|}{$\begin{array}{l}95 \% \text { Confidence Interval of the } \\
\text { Difference }\end{array}$} \\
\hline & & & Lower & Upper & p-value \\
\hline $\mathrm{RBC}\left(\times 10^{12} / \mathrm{L}\right)$ & $4.88 \pm 0.573$ & $5.35 \pm 0.533$ & -0.674 & -0.261 & $p<0.001$ \\
\hline $\mathrm{HGB}(\mathrm{g} / \mathrm{d})$ & $15.04 \pm 1.33$ & $15.59 \pm 1.25$ & -1.033 & -0.063 & $\mathrm{p}=0.027$ \\
\hline HCT (\%) & $43.29 \pm 3.71$ & $44.95 \pm 3.10$ & -2.919 & -0.403 & $p<0.010$ \\
\hline $\mathrm{MCV}(\mathrm{fl})$ & $87.37 \pm 4.98$ & $85.87 \pm 4.36$ & 0.238 & 3.226 & 0.090 \\
\hline $\mathrm{MCH}(\mathrm{pg})$ & $30.48 \pm 2.06$ & $29.52 \pm 1.66$ & 0.313 & 1.686 & 0.006 \\
\hline $\mathrm{MCHC}(g / d l)$ & $34.83 \pm 0.99$ & $34.32 \pm 0.92$ & 0.153 & 0.873 & 0.006 \\
\hline RDW (\%) & $12.87 \pm 0.59$ & $12.95 \pm 0.84$ & -0.419 & 0.253 & 0.626 \\
\hline WBC $\left(\times 10^{9} / \mathrm{L}\right)$ & $6.32 \pm 1.73$ & $6.44 \pm 1.38$ & -0.692 & 0.452 & 0.679 \\
\hline Lymphocyte (\%) & $36.02 \pm 11.20$ & $34.7 I \pm 10.04$ & -2.644 & 5.254 & 0.514 \\
\hline Neutrophil (\%) & $52.14 \pm 12.05$ & $54.72 \pm 10.44$ & -6.739 & 1.589 & 0.223 \\
\hline Lymphocyte $\left(\times 10^{9} / \mathrm{L}\right)$ & $2.16 \pm 0.59$ & $2.16 \pm 0.58$ & -0.224 & 0.219 & 0.980 \\
\hline Neutrophil $\left(\times 10^{9} / \mathrm{L}\right)$ & $3.37 \pm 1.46$ & $3.60 \pm 1.31$ & -0.745 & 0.289 & 0.384 \\
\hline Platelet $\left(\times 10^{9} / \mathrm{L}\right)$ & $248.95 \pm 58.19$ & $292.45 \pm 62.17$ & -66.418 & -20.583 & $\mathrm{p}<0.00 \mathrm{I}$ \\
\hline MPV (fl) & $|0.74 \pm| .2 \mid$ & $10.96 \pm 1.78$ & -3.492 & 3.054 & 0.895 \\
\hline
\end{tabular}

Abbreviations: HGB, hemoglobin; HCT, hematocrit; RBC, red blood cell; WBC, white blood cell; RDW, red cell distribution width; MCV, mean cell volume; MCH, mean cell hemoglobin; MCHC, mean cell hemoglobin concentration; g/dl, gram per deciliter; fl, femtoliter; pg, picogram. 
ranges. The absolute mean number of $\mathrm{RBC}\left(10^{12} / \mathrm{L}\right)$, percentages of hematocrit $(\%)(p<0.0001)$, level of hemoglobin $(\mathrm{g} / \mathrm{dl})(\mathrm{p}=0.027)$ and absolute mean number of platelets $\left(10^{9} / 1\right) \quad(p<0.0001)$ were significantly lower among the exposed subjects compared with the control group. The mean cell hemoglobin (pg) and mean cell hemoglobin concentration $(\mathrm{g} / \mathrm{dl})$ were significantly higher in the exposed participants compared with the control group, at $\mathrm{p}=0.006$.

\section{Effects of Exposure to Gasoline on Hematological Parameters}

The hematological parameters like HCT levels, RBC count, HGB concentration, platelet count, MPV value, lymphocyte percent and neutrophil percent decreased as years of exposure increased. Most participants exposed for longer than eight years had significantly lower values of hemoglobin (g/dl), PCV (\%), RBC $\left(10^{12} / \mathrm{L}\right)$ and platelet $\left(10^{9} / \mathrm{L}\right)$ compared to those exposed for $\leq 2$ years as well as 3-7 years. The average values of RBC, HGB, HCT and platelet were similar between individuals exposed for $<2$ and 3-7 years (Table 3 ).

\section{Correlation of Hematological Indices with Years of Exposure, Working Hours and Age of the Exposed Group at Mekelle City}

As illustrated in Table 4, there was a negative correlation between RBC, HGB, HCT and platelet with years of exposure $(\mathrm{r}=-0.619, \mathrm{p}<0.001, \mathrm{r}=-0.581, \mathrm{p}<0.001, \mathrm{r}=$ $-0.524, \mathrm{p}<0.001, \mathrm{r}=-0.499, \mathrm{p}=0.001)$, respectively. Whereas, absolute number of neutrophil was positively correlated with years of exposure $(r=0.337, p=0.027)$. There was also a negative correlation of $\mathrm{RBC}(\mathrm{r}=-0.418$, $\mathrm{p}=0.005), \operatorname{HGB}(\mathrm{r}=-0.368, \mathrm{p}=0.015)$ and platelet $(\mathrm{r}=$ $-0.330, \mathrm{p}=0.030)$ with age.

\section{Peripheral Blood Morphology Examination Results}

Of the examined peripheral blood films from the exposed group, $37(79.1 \%)$ of the results were normal, $4(9.3 \%)$ had macrocytosis with increasing corresponding $\mathrm{MCV}$ value, basophilic stippling inclusions and one participant had microcytic red cells with reduced $\mathrm{MCV}$ value (77.1 fl).

\section{Discussion}

This study aimed to assess the effect of gasoline and gasoline products exposure on hematological parameters among gas station workers as compared with controls in

Table 3 Comparison of the Hematological Indices with Years of Exposure in Exposed Group Using Post Hoc Analysis at Mekelle City, Tigray Region, Northern Ethiopia, from January to March $2018(n=43)$

\begin{tabular}{|c|c|c|}
\hline \multirow[t]{2}{*}{ Years of Exposure } & Parameters & \multirow[t]{2}{*}{ p-value } \\
\hline & $\operatorname{RBC}\left(10^{12} / I\right)($ Mean $\pm S D)$ & \\
\hline $\begin{array}{l}\leq 2 \text { year vs } 3-7 \text { year } \\
\leq 2 \text { year vs } \geq 8 \text { year } \\
3-7 \text { year vs } \geq 8 \text { year }\end{array}$ & $\begin{array}{l}5.17 \pm 0.40 \text { vs } 5.07 \pm 0.58 \\
5.17 \pm 0.40 \text { vs } 4.37 \pm 0.40 \\
5.07 \pm 0.58 \text { vs } 4.37 \pm 0.40\end{array}$ & $\begin{array}{l}0.587 \\
<0.0001 \\
<0.0001\end{array}$ \\
\hline \multicolumn{3}{|c|}{ HGB (g/dl) } \\
\hline $\begin{array}{l}\leq 2 \text { year vs } 3-7 \text { year } \\
\leq 2 \text { year vs } \geq 8 \text { year } \\
3-7 \text { year vs } \geq 8 \text { year }\end{array}$ & $\begin{array}{l}|5.72 \pm| .08 \text { vs } 15.25 \pm \mid .55 \\
|5.72 \pm| .08 \text { vs } 14.03 \pm 0.70 \\
|5.25 \pm| .55 \text { vs } 14.03 \pm 0.70\end{array}$ & $\begin{array}{l}0.271 \\
<0.0001 \\
0.010\end{array}$ \\
\hline \multicolumn{3}{|c|}{ НCT (\%) } \\
\hline $\begin{array}{l}\leq 2 \text { year vs } 3-7 \text { year } \\
\leq 2 \text { year vs } \geq 8 \text { year } \\
3-7 \text { year vs } \geq 8 \text { year }\end{array}$ & $\begin{array}{l}45.15 \pm 2.94 \text { vs } 43.55 \pm 4.86 \\
45.15 \pm 2.94 \text { vs } 40.80 \pm 1.59 \\
43.55 \pm 4.86 \text { vs } 40.80 \pm 1.59\end{array}$ & $\begin{array}{l}0.202 \\
<0.001 \\
0.041\end{array}$ \\
\hline \multicolumn{3}{|c|}{ WBC $\left(10^{9} / \mathrm{L}\right)$} \\
\hline $\begin{array}{l}\leq 2 \text { year vs } 3-7 \text { year } \\
\leq 2 \text { year vs } \geq 8 \text { year } \\
3-7 \text { year vs } \geq 8 \text { year }\end{array}$ & $\begin{array}{l}5.90 \pm 1.28 \text { vs } 6.11 \pm 1.65 \\
5.90 \pm 1.28 \text { vs } 7.01 \pm 2.13 \\
6.11 \pm 1.65 \text { vs } 7.01 \pm 2.13\end{array}$ & $\begin{array}{l}0.744 \\
0.078 \\
0.187\end{array}$ \\
\hline \multicolumn{3}{|c|}{ LYM (\%) } \\
\hline $\begin{array}{l}\leq 2 \text { year vs } 3-7 \text { year } \\
\leq 2 \text { year vs } \geq 8 \text { year } \\
3-7 \text { year vs } \geq 8 \text { year }\end{array}$ & $\begin{array}{l}37.47 \pm 9.84 \text { vs } 41.07 \pm 12.32 \\
37.47 \pm 9.84 \text { vs } 29.91 \pm 9.54 \\
41.07 \pm 12.32 \text { vs } 29.91 \pm 9.54\end{array}$ & $\begin{array}{l}0.366 \\
0.053 \\
0.010\end{array}$ \\
\hline \multicolumn{3}{|c|}{ NUE (\%) } \\
\hline $\begin{array}{l}\leq 2 \text { year vs } 3-7 \text { year } \\
\leq 2 \text { year vs } \geq 8 \text { year } \\
3-7 \text { year vs } \geq 8 \text { year }\end{array}$ & $\begin{array}{l}50.80 \pm 10.47 \text { vs } 46.49 \pm 13.7 \\
50.80 \pm 10.47 \text { vs } 58.63 \pm 9.83 \\
46.49 \pm 13.7 \text { vs } 58.63 \pm 9.83\end{array}$ & $\begin{array}{l}0.318 \\
0.062 \\
0.009\end{array}$ \\
\hline \multicolumn{3}{|c|}{ Platelet $\left(10^{9} / \mathrm{l}\right)$} \\
\hline $\begin{array}{l}\leq 2 \text { year vs } 3-7 \text { year } \\
\leq 2 \text { year vs } \geq 8 \text { year } \\
3-7 \text { year vs } \geq 8 \text { year }\end{array}$ & $\begin{array}{l}267.05 \pm 54.74 \text { vs } 280.16 \pm 39.07 \\
267.05 \pm 54.74 \text { vs } 200.21 \pm 45.54 \\
280.16 \pm 39.07 \text { vs } 200.21 \pm 45.54\end{array}$ & $\begin{array}{l}0.472 \\
<0.0001 \\
<0.0001\end{array}$ \\
\hline
\end{tabular}

Abbreviations: $\mathrm{HGB}$, hemoglobin; $\mathrm{HCT}$, hematocrit; RBC, red blood cell; WBC, white blood cell; LYM, lymphocyte; NUETRO, neutrophil; Cl, confidence interval; g/ dl, gram per deciliter. 
Table 4 Correlation of Hematological Indices with Years of Exposure, Working Hours, and Age for the Exposed Group Using ANOVA Statistical Analysis at Mekelle City Tigray Region, Northern Ethiopia, from January to March 2018 ( $n=43)$

\begin{tabular}{|c|c|c|c|c|c|c|}
\hline \multirow[t]{2}{*}{ Parameters } & \multicolumn{2}{|c|}{ Years of Exposure } & \multicolumn{2}{|c|}{ Working Hours } & \multicolumn{2}{|c|}{ Age of Exposed } \\
\hline & $\mathbf{r}$ & p-value & $\mathbf{r}$ & p-value & $\mathbf{r}$ & p-value \\
\hline $\operatorname{RBC}\left(10^{9} / 1\right)$ & -0.619 & $<0.001$ & 0.292 & 0.057 & -0.418 & 0.005 \\
\hline HGB $(g / d l)$ & -0.581 & $<0.001$ & 0.266 & 0.085 & -0.368 & 0.015 \\
\hline HCT (\%) & -0.524 & 0.000 & 0.332 & 0.129 & -0.270 & 0.080 \\
\hline MCV (fl) & 0.152 & 0.330 & -0.195 & 0.209 & 0.172 & 0.269 \\
\hline $\mathrm{MCH}(\mathrm{pg})$ & 0.044 & 0.779 & -0.273 & 0.076 & 0.050 & 0.750 \\
\hline WBC $\left(10^{9} / 1\right)$ & 0.268 & 0.082 & 0.017 & 0.912 & 0.166 & 0.289 \\
\hline Lymphocyte $\left(10^{9} / \mathrm{l}\right)$ & -0.041 & 0.794 & -0.054 & 0.730 & -0.022 & 0.890 \\
\hline Neutrophil $\left(10^{9} / I\right)$ & 0.337 & 0.027 & 0.000 & 1.000 & 0.154 & 0.324 \\
\hline Platelet $\left(10^{9} / \mathrm{l}\right)$ & -0.499 & 0.001 & 0.160 & 0.307 & -0.330 & 0.030 \\
\hline MPV (fl) & 0.222 & 0.153 & 0.242 & 0.117 & 0.113 & 0.470 \\
\hline
\end{tabular}

Note: Bold text is to indicate test is significant at $\mathrm{p}<0.05$.

Abbreviations: HGB, hemoglobin; HCT, hematocrit; RBC, red blood cell; MCV, mean cell volume; MCH, mean cell hemoglobin; WBC, white blood cell; MPV, mean platelet volume; $\mathrm{Cl}$, confidence interval; g/dl, gram per deciliter; fl, femtoliter.

Mekelle City, Tigray Region. It also tried to identify risk factors associated with gasoline product exposure in gas station workers and the relationship between duration of gasoline exposure and hematological parameters. The findings are pointing toward the fact that gasoline and its content have adverse effects on the hematological parameters with a longer period of exposure.

The observed statistically significant decrease in the measured parameters of exposed participants, such as red blood cell (RBC), hemoglobin (HGB) concentration, hematocrit (HCT) and platelet (PLT) count, compared to controls may be due to several toxic effects arising from the gasoline and its products. Benzene, one of the main constituents of gasoline, is a well-known systemic toxicant in humans and a cause of aplastic anemia. It is hematotoxic and depresses the bone marrow, leading to pancytopenia (a general depression of erythrocytes (red blood cells), leucocytes (white blood cells) and thrombocytes (platelets). ${ }^{9}$ These studies demonstrate that benzene is indeed a hematotoxicant.

The results of the present study showed that the mean hemoglobin concentration, mean RBCs count, mean hematocrit value, platelet count of gas station workers were significantly lower than those of the comparison group. Decreases in hemoglobin content and RBC count could be attributed to shortened life span of RBC as well as impairment of heme synthesis by the metabolic end product of free radicals of benzene and other aliphatic hydrocarbon constituents of gasoline. These free radicals can alter the erythrocyte membrane and heme protein synthesis in bone marrow. ${ }^{10,11,14}$ This result is similar with the study conducted in hematological assessment of gasoline exposure among gas station workers by Schnatter et al, ${ }^{28}$ Nair et al, ${ }^{29,30}$ and Neghab et al. ${ }^{27} \mathrm{~A}$ decrease in RBC count can lead to a decrease in PCV. But the hematocrit, RBC count, hemoglobin and platelet count were not consistent with those reports which described the hematological changes of individuals occupationally exposed to gasoline as significantly high, such as Saadat et $\mathrm{al}^{31}$ and Firouzkouhi et al. $^{32}$ Reduction in the value of RBC, HCT and HGB content as reported in this study would eventually lead to anemia, a condition which agrees with the report of Uko et al. ${ }^{33}$

In this study, MCV, mean $\mathrm{MCH}$ and $\mathrm{MCHC}$ value were significantly higher in exposed than comparison group. This finding is in agreement with another study by Firouzkouhi et $\mathrm{al}^{32}$ and by Nair et $\mathrm{al}^{29}$ as they observed statistically significant increases in $\mathrm{MCH}$ and $\mathrm{MCHC}$ values. Even though the MCV value is not significantly higher in the exposed group, it shows a similar increase to the result reported by Schnatter et al. ${ }^{28}$ The increases in $\mathrm{MCV}, \mathrm{MCH}$ and $\mathrm{MCHC}$ in this study can be due to macrocytosis induced by benzene, because benzene is an ingredient of gasoline. It has been established that toxic constituents of petroleum such as benzene and lead are activated in the bone marrow, where the substances exert cytotoxic effects that could be mediated through destruction in DNA function. A defect in DNA synthesis that interferes with cellular proliferation and maturation can lead to large' erythrocytes. ${ }^{20}$

This study also indicates that total RBC count, hemoglobin concentration and HCT value decreased in gas 
station workers as the duration of exposure increased from less than 2 years to more than 8 years. These findings were different from the studies conducted by Uzma et $\mathrm{al}^{34}$ which showed that, during the early period of exposure (1-5 years and 5-10 years), the average $\mathrm{Hb}, \mathrm{HCT}$ and $\mathrm{RBC}$ counts were unchanged, but as the years of exposure increased to more than 10 years, there was a statistically significant increase in the concentration of $\mathrm{Hb}, \mathrm{RBC}$ count and HCT value. Platelet counts of the present study significantly decreased as year of exposure increased from two years to eight years and is consistent with a previous study by Uzma et al. ${ }^{34}$ Nevertheless, the decrease in total RBC count, hemoglobin concentration and HCT value in workers with longer periods of exposure as the duration of exposure increases from less than 2 year to more than 8 years were consistent to study conducted by Uko et al. ${ }^{33} \mathrm{In}$ the present study, the reported WBC count was unchanged as year of exposure increased but it was decreased in the study done by Uko et al. ${ }^{33}$

The peripheral blood smear of the study participants showed basophilic stippling and macrocytosis $(9.3 \%)$. In line with this finding, Firouzkouhi et $\mathrm{al}^{32}$ and Uko et $\mathrm{al}^{33}$ reported basophilic stippling and macrocytosis, respectively, from the gasoline exposed attendants. However, this finding is not consistent with Elderdery et $\mathrm{al}^{35}$ which reported a microcytic picture in $50 \%$ of their participants and a quarter (26\%) showed a normocytic picture. This inconsistency might be because of population difference, performance and the gasoline constituent difference in the study.

Finally, this study has some drawbacks. There were no records for baseline and periodic medical examination of workers to identify changes that could be attributed to gasoline exposure. Being a small-scale study with a few gas station attendants and participants limits the generalization of results to the total populations of gas station attendants in other places. However, in the absence of any similar data, this study has also its own strength in that it assesses the effect of occupational exposure to gasoline for the first time, which could attract attention for appropriate intervention.

\section{Conclusion and Recommendation}

The present study has shown that occupational exposure to gasoline and its constituent products has a significant effect on some hematological parameters. Moreover, long-term exposure to gasoline-specific components of gasoline, such as benzene, toluene, ethylene, xylene and lead, might have some effects on the human hematopoietic system leading to suppressed bone marrow or might cause ineffective erythropoiesis and thrombopoiesis. It has been observed that chronic ingestion of gasoline might result in a significant reduction in $\mathrm{RBC}$ count, $\mathrm{Hb}$ concentration and total platelet count. The toxicity of gasoline components usually causes RBC inclusion (basophilic stippling, Heinz's bodies, and pappenheimer bodies) and oxidation of hemoglobin, which decrease the life of RBC and cause hemoglobin synthesis defects, hence decreasing the parameters.

Gas station workers with chronic exposure to gasoline products should have periodic medical examinations including the evaluation of their hematological profile and measurement of blood benzene and blood lead levels. In this regard, gas station owners should provide basic personal protective equipment like face masks and the government should make blood benzene and blood lead level analyzer auto machines available. Further research is recommended to include other gas station workers in the other parts of the country with large sample sizes of these workers occupationally exposed to gasoline.

\section{Abbreviations}

AML; acute myeloid leukemia, $\mathrm{CBC}$; complete blood count, CI; confidence interval, DNA; deoxyribo nucleic acid, fl; femtoliter, GST; glutathione S-transferase, HGB; $\mathrm{g} / \mathrm{dl}$; gram per deciliter, hemoglobin, HCT; hematocrit, $\mathrm{HQ}$; hydroquinone, $\mathrm{K}_{2}$ EDTA; di-potassium ethylene diamine tetra acetic acid, $\mathrm{km}$, kilometr, $\mathrm{MCH}$; mean cell hemoglobin, MCHC; mean cell hemoglobin concentration, MCV; mean cell volume, MPV; mean platelet volume, PCV; packed cell volume, PPM; parts per million, pg; picogram, QC; quality controls, RBC; red blood cell, RDW; red blood cell distribution width, ROS; reactive oxygen species, SD; standard deviation, SPSS; Statistical Package for Social Sciences, TLC; total leukocyte count, VOCs; volatile organic compounds, WBC; white blood cells.

\section{Data Sharing Statement}

Not all data will be made available to protect the participants' confidentiality. But the row data can be obtained from the corresponding author upon reasonable request.

\section{Acknowledgments}

We would like to thank Addis Ababa University, College of Health Science and Department of Medical Laboratory 
Science for financial support. The administrative office of Ayder Comprehensive Specialized Hospital and central laboratory workers are gratefully acknowledged for permitting and supporting this study in analysis of hematological parameters. Our sincere thanks also go to the study participants for their kind collaboration in filling in questionnaires and giving biological samples, which allowed further insights on gasoline exposure.

\section{Author Contributions}

All authors have contributed from inception to shaping of the research design, commenting on the paper and its final approval, acquisition of data, analysis and interpretation of data, drafting the manuscript, revising the manuscript critically for important intellectual content, read and made comments on the manuscript for submission, gave final approval of the manuscript version to be published and agreed to be accountable for every aspect of the work.

\section{Disclosure}

The authors declared no conflicts of interest for this work nor regarding the publication of this paper. This manuscript's thesis was uploaded to Addis Ababa University electronic thesis library based on an author's thesis requirement for academic purposes and is available online at: http://etd.aau.edu.et/bitstream/handle/123456789/ 13806/Gebre\%20Teklu.pdf?sequence=1\&isAllowed=y.

\section{References}

1. Doulatov S, Notta F, Laurenti E, Dick JE. Hematopoiesis: a human perspective. Cell Stem Cell. 2012;10(2):120-136. doi:10.1016/j. stem.2012.01.006

2. Uzma N, Khaja MS, Salar BM, Aziz N, David MA, Reddy VD. Impact of organic solvents and environmental pollutants on the physiological function in petrol filling workers. Int $J$ Environ Res Public Health. 2008;5(3):139-146.

3. Khalade A, Jaakkola MS, Pukkala E, Jaakkola JJ. Exposure to benzene at work and the risk of leukemia: a systematic review and meta-analysis. Environ Health. 2010;9(1):31. doi:10.1186/1476069X-9-31

4. Snyder R. Overview of the toxicology of benzene. J Toxicol Environ Health A. 2000;61(5-6):339-346. doi:10.1080/00984100050166334

5. Lee SY, Park HJ, Best-Popescu C, Jang S, Park YK. The effects of ethanol on the morphological and biochemical properties of individual human red blood cells. PLoS One. 2015;10(12):e0145327.

6. Jasper MN, Martin SA, Oshiro WM, Ford J, Bushnell PJ, El-Masri H. Application of biologically based lumping to investigate the toxicokinetic interactions of a complex gasoline mixture. Environ Sci Technol. 2016;50(6):3231-3238. doi:10.1021/acs.est.5b05648

7. Folabi T, Phan T. Evaluation of Volatile Organic Compounds and Polyaromatic Hydrocarbons in Barker Reservoir in Houston, Texas after the 2017 Hurricane Harvey. Am J Anal Chem. 2020;11(11):376388.
8. Al Madhoun WA, Ramli NA, Yahaya AS, Yusof NF, Ghazali NA, Sansuddin NU. A framework for monitoring and modelling of BTEX in various development statuses in Penang Malaysia. Proceeding of the international conference on environment. 2008; (ICENV08), Penang, Malaysia.

9. Okonkwo CO, Ehileboh AD, Nwobodo E, Dike CC. The effects of acute gasoline vapour inhalation on some hematological indices of albino Wistar rats. J Acute Dis. 2016;5(2):123-125. doi:10.1016/j.joad.2015.11.005

10. Cronkite EP, Drew RT, Inoue T, Hirabayashi Y, Bullis JE. Hematotoxicity and carcinogenicity of inhaled benzene. Environ Health Perspect. 1989;82:97-108. doi:10.1289/ehp.898297

11. World Health Organization. Benzene. In: Air Quality Guidelines for Europe. $3^{\text {rd }}$ ed. Copenhagen: WHO Regional Office for Europe; 2000:pp 62-66.

12. Kim SY, Choi JK, Cho YH, Chung EJ, Paek D, Chung HW. Chromosomal aberrations in workers exposed to low levels of benzene: association with genetic polymorphisms. Pharmacogenet Genom. 2004;14(7):453-463. doi:10.1097/01.fpc.0000114751.08559.7b

13. Rinsky RA, Smith AB, Hornung R, et al. Benzene and leukemia. New Engl $j \quad$ Med. 1987;316(17):1044-1050. doi:10.1056/ NEJM198704233161702

14. Ross D. The role of metabolism and specific metabolites in benzene-induced toxicity: evidence and issues. J Toxicol Environ Health Part A. 2000;61(5-6):357-372. doi:10.1080/ 00984100050166361

15. Smith MT. The mechanism of benzene-induced leukemia: a hypothesis and speculations on the causes of leukemia. Environ Health Perspect. 1996;104(supply 6):1219-1225. doi:10.1289/ ehp. 961041219

16. Weng MW, Lee HW, Park SH, et al. Aldehydes are the predominant forces inducing DNA damage and inhibiting DNA repair in tobacco smoke carcinogenesis. Proc Nat Acad Sci USA. 2018;115(27): E6152-E6161. doi:10.1073/pnas.1804869115

17. Soares M, Woiciechowski AL, Kozliak EI, Paca J, Soccol CR. Biofiltration of gasoline and ethanol-amended gasoline vapors. J Environ Sci Health, Part A. 2012;47(7):1008-1016. doi:10.1080/ 10934529.2012.667316

18. Carbonari D, Chiarella P, Mansi A, Pigini D, Iavicoli S, Tranfo G. Biomarkers of susceptibility following benzene exposure: influence of genetic polymorphisms on benzene metabolism and health effects. Biomark Med. 2016;10(2):145-163. doi:10.2217/bmm.15.106

19. Mitri S, Fonseca AS, Otero UB, Tabalipa MM, Moreira JC, Sarcinelli PD. Metabolic polymorphisms and clinical findings related to benzene poisoning detected in exposed brazilian gas-station workers. Int J Environ Res Public Health. 2015;12(7):8434-8447. doi:10.3390/ijerph120708434

20. Khisroon M, Gul A, Khan A, Ali N, Zaidi F, Rasheed SB. Comet assay based DNA evaluation of fuel filling stations and automobile workshops workers from Khyber Pakhtunkhwa province, Pakistan. J Occup Med Toxicol. 2015;10(1):10-27. doi:10.1186/s12995-015-0069-2

21. Beceren A, Akdemir N, Omurtag GZ, Tatlıpınar ME, Şarda S. DNA damage in gasoline station workers caused by occupational exposure to petrol vapour in turkey. ACTA PharmaceuticaSciencia. 2016;54 (1):53-62. doi:10.23893/1307-2080.APS.0545

22. Knutsen JS, Kerger BD, Finley B, Paustenbach DJ. A calibrated human PBPK model for benzene inhalation with urinary bladder and bone marrow compartments. Risk Analysis. 2013;33 (7):1237-1251. doi:10.1111/j.1539-6924.2012.01927.x

23. Pemble S, Schroeder KR, Spencer SR, et al. Human glutathione S-transferase theta (GSTT1): cDNA cloning and the characterization of a genetic polymorphism. Biochemical Journal. 1994;300 (1):271-276. doi:10.1042/bj3000271

24. Sun R, Zhang J, Yin L, Pu Y. Investigation into variation of endogenous metabolites in bone marrow cells and plasma in $\mathrm{C} 3 \mathrm{H} / \mathrm{He}$ mice exposed to benzene. Int $J$ Mol Sci. 2014;15(3):4994-5010. doi:10.3390/ijms15034994 
25. Hayes RB, Zhang L, Yin S, et al. Genotoxic markers among butadiene polymer workers in China. Carcinogenesis. 2000;21(1):55-62. doi:10.1093/carcin/21.1.55

26. Li K, Jing Y, Yang C, Liu S, Zhao Y, He X. Increased leukemia associated gene expression in benzene-exposed workers. Sci Rep. 2014;4:5369. doi:10.1038/srep05369

27. Neghab M, Hosseinzadeh K, Hassanzadeah J. Hematological study of petrol station workers exposed to unleaded petrol. Toxicol Environ Chem. 2014;96(6):951-961. doi:10.1080/02772248.2014.979828

28. Robert Schnatter A, Kerzic PJ, Zhou Y, et al. Peripheral blood effects in benzene-exposed workers. Chem Biol Interact. 2010;184(12):174-181. doi:10.1016/j.cbi.2009.12.020

29. Nair DS, Bedekar MY, Agrawal MJ. Deleterious effects of petrol fumes on erythrocytes. IJHSR. 2015;5(9):237-241.

30. Bedekar MY, Nair DS, Agrawal MJ. Toxic effect of petrol fumes on white blood corpuscles. Ann Appl Bio-Sci. 2015;2(3):57-59.

31. Saadat M, Bahaoddini A. Hematological changes due to chronic exposure to natural gasleakage in polluted areas of Masjid-i-Sulaiman (Khozestan province, Iran). Ecotoxicol Environ Saf. 2004;58(2):273-276. doi:10.1016/j.ecoenv.2003.07.005

32. Firouzkouhi M, Abdollahimohammad A, Babaiepur-Diveshali M, Firouzkouhi A, Shaikh M. Effects of gasoline on blood, kidney and liver parameters of unregulated gasoline traders. Der Pharmacia Lettre. 2016;8(8):58-61.
33. Uko EK, Erhabor O, Bashiru GA, et al. Some hematological indices among petrol station attendants occupationally exposed to premium motor spirit in Sokoto, North Western, Nigeria. J Int Res Med Pharm Sci. 2015;4(2):53-58.

34. Uzma N, Salar KM, Kumar S, Aziz N, David MA, Reddy VD. Impact of organic solvents and environmental pollutants on the physiological function in petrol filling workers. Int $J$ Environ Res Public Health. 2008;5(3):139-146. doi:10.3390/ijerph5030139

35. Elderdery AY, Elnour AM, Ali NY, et al. Alterations in hematological parameters among workers of fuel stations in White Nile State, Sudan. Int J Biomed Adv Res. 2015;6(11):780-784.

36. Sysmex XP-300TM Automated Hematology Analyzer. Sysmex; 2015. Available from: https://www.sysmex.com/us/en/Products/ Hematology/3PartDiff/Pages/XP-300-Hematology-Analyzer.aspx. Accessed September 13, 2021.
Journal of Blood Medicine

\section{Publish your work in this journal}

The Journal of Blood Medicine is an international, peer-reviewed, open access, online journal publishing laboratory, experimental and clinical aspects of all aspect pertaining to blood based medicine including but not limited to: Transfusion Medicine; Blood collection, Donor issues, Transmittable diseases, and Blood banking logistics; Immunohematology; Artificial and alternative blood based

\section{Dovepress}

therapeutics; Hematology; Biotechnology/nanotechnology of blood related medicine; Legal aspects of blood medicine; Historical perspectives. The manuscript management system is completely online and includes a very quick and fair peer-review system. Visit http://www.dovepress.com/testimonials.php to read real quotes from published authors. 